\title{
Nuisance flies on Australian cattle feedlots: immature populations
}

\author{
J. A. HOGSET TE ${ }^{1}$, R. URE C H $\mathrm{H}^{2}$, P. E. GRE E N ${ }^{2}, A . S K E R M A N^{3}$, \\ M. M. E L S O N-H A R R I S ${ }^{2}$, R. L. B R I G H T ${ }^{2}$ and G. W. B R O W N ${ }^{2}$ \\ ${ }^{1}$ U.S. Department of Agriculture-Agricultural Research Service (USDA-ARS), Center for Medical, Agricultural and Veterinary \\ Entomology, Gainesville, FL, U.S.A., ${ }^{2}$ Agri-Science Queensland, Yeerongpilly, Qld, Australia and ${ }^{3}$ Agri-Science Queensland, \\ Toowoomba, Qld, Australia
}

\begin{abstract}
Species composition, seasonality and distribution of immature fly populations on a southern Queensland feedlot during 2001-2003 were determined. Similar data were collected on feedlots in central New South Wales and central Queensland. The fly species recovered in the highest numbers were Musca domestica L. (Diptera: Muscidae), Stomoxys calcitrans L. (Diptera: Muscidae) and Physiphora clausa Macquart (Diptera: Ulidiidae). Houseflies were the dominant species at all feedlots. Houseflies preferred the warmer months from October to June, but stable flies preferred the cooler months and peaked in spring (September-November) and autumn (March-May). Larval abundance ratings recorded in the feedlot and numbers of larvae extracted in the laboratory from corresponding samples followed similar trends. Larvae of $M$. domestica were most abundant in the hospital and induction area and least abundant in horse stables and yards. Pupae of $M$. domestica were abundant in the hospital and induction area and drains, but least abundant in horse stables and yards. Larvae of S. calcitrans were most abundant in drains and least abundant in horse stables and yards. Pupae of S. calcitrans were most numerous in drains and least numerous in old cattle pens. Feedlot design and management had little effect on fly reduction.
\end{abstract}

Key words. Musca domestica, Stomoxys calcitrans, development sites, management, seasonality, species composition.

\section{Introduction}

Flies can become a nuisance in and around intensive animal facilities for many reasons (Hogsette \& Farkas, 2000). They can annoy animals and people, cause complaints from neighbours, and lead to production losses and animal welfare problems (Campbell \& Berry, 1989; Catangui et al., 1997; Cook et al., 1999; Campbell et al., 2001). Flies can transmit pathogens (Greenberg, 1971; De Jesus et al., 2004; Graczyk et al., 2005) and the management of large populations may require the application of insecticides, with potential for environmental pollution, health and safety-related issues and the development of insecticide resistance in target populations
(Cilek \& Greene, 1994; Kocisova et al., 2002; Marçon et al., 2003; Mullens et al., 2010; Pitzer et al., 2010).

Cattle feedlots generate large amounts of manure and other substrates suitable for the development of filth flies, especially the housefly Musca domestica L. and the stable fly Stomoxys calcitrans L. (Skoda et al., 1991, 1993; Hogsette, 1996). Considerable efforts have been made to develop efficacious fly management programmes that are not based on longterm use of insecticides. Integrated management systems incorporate a variety of components, such as improved sanitation (Eghball \& Power, 1994; Thomas et al., 1996), biological control (Hogsette, 1999; Floate, 2003; Skovgard \& Nachman, 2004) and traps (Kaufman et al., 2001). To design and implement an

Correspondence: Jerome A. Hogsette, USDA-ARS CMAV E, 1600 SW 23rd Drive, Gainesville, FL 32608, U.S.A. Tel.: +1 352 374 5933; Fax: +1 352374 5922; E-mail: jerry.hogsette@ars.usda.gov 
integrated fly management programme, the species complex and the seasonal and spatial distributions of target pests and their natural enemies must be known.

The Australian cattle feedlot industry has rapidly expanded and has capacity for one million head of cattle (Australian Lot Feeders' Association, 2009). More than $80 \%$ of feedlot cattle are located in grain-growing districts in Queensland and New South Wales. Season-long investigations of immature fly populations on Australian cattle feedlots are not reported in the literature. Studies to define the species complex of adult flies (Levot \& Hughes, 1995) and their insecticide resistance levels (Levot \& Hughes, 1989) have been performed on poultry farms in New South Wales. However, the fly species complex and the level of insecticide pressure on poultry farms can be quite different from those found on feedlots. Many Australian cattle feedlot and dairy operators have reported problems with large fly populations (R. Urech, unpublished data, 2001).

This research was conducted to obtain information needed for the development of integrated management programmes for nuisance flies on Australian cattle feedlots. The objectives were to define the species composition, seasonality and preferred developmental locations in selected feedlot habitats of nuisance fly immatures. Also investigated were the effects of feedlot design and management practices on the immature fly community. Because of labour constraints, the in-depth research was performed at a large feedlot in southern Queensland. Brief studies were conducted at feedlots to the north and south of the main site.

\section{Materials and methods}

The selection of the three feedlots used in this study was based on similarities in physical qualities [i.e. overall size, number of animals ( \pm 13 000), breed types (Bos indicus -derived Droughtmaster and Santa Gertrudis-Bos taurus crosses; longer-fed Angus, Murray Greys, Shorthorns and Wagyu], feed types (high-moisture rolled grain, primarily sorghum, supplemented with barley, wheat and corn), feeding practices, management systems, and isolation from other feedlots. Feedlots were located in three climatic zones, but within the major feedlot areas of Australia.

The primary research was conducted on the southern Queensland (SQ) feedlot on the Darling Downs. The climate is characterized by hot, dry summers and cold winters (Table 1). Short investigations were performed on one feedlot in central New South Wales (CNSW) in a region with a temperate climate, and on another feedlot in central Queensland
(CQ), which has hot, dry summers and warm winters (Table 1).

\section{Species composition and seasonality of fly larvae and pupae at selected developmental sites}

The species composition and seasonality of the immature fly populations were determined by sampling larvae and pupae from the following selected feedlot sites: sedimentation ponds; horse stables and yards; manure stockpiles; a selected cattle pen in the older section of the feedlot (minimal pen surface gradient); a selected cattle pen in the newer section of the feedlot (optimal 3\% pen surface gradient); silage pits; drains, and the hospital and induction area. All sites at the SQ feedlot were sampled and rated weekly from the end of October 2001 to the end of December 2001 and then fortnightly to the end of October 2003. The exceptions were the hospital and induction area, and drains, which were only used from January to October 2003. Similar sampling was carried out at the CNSW and CQ feedlots during 14-16 January 2003 and 25-27 March 2003, respectively. Samples obtained from the latter two feedlots represent a short-term record of the nuisance fly species present and their relative abundances. Labour constraints did not permit longterm sampling at all three feedlots.

Samples were collected with a small trowel and consisted of $500 \mathrm{~mL}$ of cattle manure, feed residues or soil containing fly larvae and pupae. Within each selected site, samples were taken from five predetermined locations during each collection interval (e.g. in the cattle pens, samples were taken near the feed bunk, in the middle of the pen, and under the side and back fences). Because of the relatively small sizes of the hospital and induction area, and the horse stables, samples were collected from only three and two of the five possible locations at these sites, respectively, in 2003. This sampling regime allowed us to determine major fly breeding sites and locations within sites.

As samples were collected from each location within each site, larval and pupal numbers were visually estimated and abundance ratings were assigned for each stage. Whole number abundance rating values from 0 to 5 correspond to $0,1-10$, $11-25,26-75,76-300$ and $>300$ larvae or pupae, respectively. If the number of larvae or pupae was in the upper $20 \%$ of an abundance range, a half rating was allocated (e.g. if the number of larvae in a sample $=9$, the sample would be given a rating of 1.5 instead of 1). The average of the abundance ratings for the sample locations within each site represented the larval and pupal abundance ratings for each site.

Table 1. Feedlot locations, from north to south, and pertinent climate data for the period 2001-2003.

\begin{tabular}{|c|c|c|c|c|c|c|}
\hline $\begin{array}{l}\text { Feedlot } \\
\text { location }\end{array}$ & Latitude & Longitude & $\begin{array}{l}\text { Mean maximum summer } \\
\text { temperature, }{ }^{\circ} \mathrm{C}\end{array}$ & $\begin{array}{l}\text { Mean summer } \\
\text { rainfall, } \mathrm{mm}\end{array}$ & $\begin{array}{l}\text { Summer rain } \\
\text { days, mean, } n\end{array}$ & $\begin{array}{l}\text { Mean minimum winter } \\
\text { temperature, }{ }^{\circ} \mathrm{C}\end{array}$ \\
\hline Central Qld & $23^{\circ} 45^{\prime} \mathrm{S}$ & $148^{\circ} 31^{\prime} \mathrm{E}$ & 35.3 & 76.2 & 5.6 & 8.8 \\
\hline Southern Qld & $27^{\circ} 02^{\prime} \mathrm{S}$ & $151^{\circ} 19^{\prime} \mathrm{E}$ & 31.7 & 85.0 & 5.6 & 4.9 \\
\hline Central NSW & $31^{\circ} 28^{\prime} \mathrm{S}$ & $150^{\circ} 35^{\prime} \mathrm{E}$ & 30.3 & 90.9 & 7.2 & 6.1 \\
\hline
\end{tabular}

Q1d, Queensland; NSW, New South Wales.

Data sourced from CLIMARC (www.bom.gov.au/climate/how/climarc.shtml). 
After abundance ratings were recorded, samples of larvae and pupae were maintained at $\sim 10{ }^{\circ} \mathrm{C}$ and then processed in the laboratory, usually within $24-48 \mathrm{~h}$ of collection. Because of the difficulty of finding and identifying first- and second-instar larvae, only third-instar larvae and pupae were separated from samples. Larvae and pupae were separated using sequential flotation in water and saturated aqueous $\mathrm{NaCl}$ solution, respectively. Extracted larvae and pupae were identified and counted. In samples with high numbers of larvae and/or pupae, aliquots of 100 pupae and 100-200 larvae were identified. One hundred (or all if $n<100$ ) intact pupae from each site were placed individually in size 00 gelatine capsules and held at $27{ }^{\circ} \mathrm{C}$ for 35 days, which was ample time for the emergence of flies and parasitic hymenoptera. Emerged flies and intact pupae were then identified.

\section{Weather data}

Study period and longterm (50 years) weather data were obtained from the Department of Natural Resources and Mines Queensland (DNR\&M) SILO website (CLIMARC, 2006), based on the GPS coordinates of the feedlots.

Effects of feedlot design and management practices at the $S Q$ feedlot

Differences in the slopes of old and new pens in the SQ feedlot allowed us to assess the effects of these features on fly breeding. Pens in the newer section had a 3\% surface slope, which is considered optimal by the industry for good drainage and odour control; pens in the older section had a minimal slope. Pens added to the new section in 2002 had a concrete base that extended about $50 \mathrm{~cm}$ under the fences, whereas pens built before 2002 in the new section and all pens in the old section had a base of compacted earth under the fences. The base of the selected pen in the new section consisted of compacted earth in the first part (October 2001 to 8 January 2003) and concrete in the second part (22 January to 15 October 2003) of the monitoring programme. In addition, new pens were partially covered with shade cloth, under which cattle tended to congregate in hot weather.

Certain management practices, such as removing manure from under fence lines and from pens and sedimentation ponds, were scheduled at variable times by the feedlot manager. When cleaning was carried out, we were able to assess its impact on the immature fly populations. The routine feedlot cleaning schedule during the monitoring period changed when feedlot ownership changed. Cleaning activities were recorded by feedlot staff in a feedlot workbook. Our information was obtained from this workbook and from the observations and notes we recorded during each visit. Cleaning of the sedimentation pond and the monitored pens in the new and old sections was of particular interest. Surface manure in all pens in the feedlot was routinely loosened with a box scraper, formed into a mound in the centre of the pen and removed at varying intervals. Manure accumulations under fence lines were pushed into the pens and moved when pens were scraped.
Four major applications of residual insecticides and/or granular housefly sugar baits (Table 2) were made at the SQ feedlot during our fly monitoring period. Residuals were sprayed onto feed bunks and other adult fly aggregation sites. Housefly sugar bait was used in the induction and hospital areas when necessary and in the feed mill on several occasions in each season. Pesticides were selected by feedlot managers and all applications were made by feedlot staff. Applications were infrequent and decisions to apply were generally based on a perceived need rather than a routine schedule. The impact of the chemical treatments on larvae at the application sites was estimated by comparing changes in the larval population curves on or after pesticide application dates.

Of the insecticides used (Table 2), betacyfluthrin ( $\operatorname{Solfac}^{\circledR}$ Pro Residual Insecticide, $25 \mathrm{~g} / \mathrm{L}$ AC; Bayer Environmental Science, East Hawthorn, Vic, Australia), an adulticide, should not affect larval populations. However, trichlorfon (Neguvon ${ }^{\circledR}$ SP, $800 \mathrm{~g} / \mathrm{kg}$ AC; Bayer AG, Leverkusen, Germany; Dipterex ${ }^{\circledR} 500$ SL, 500 g/L AC; United Phosphorus Ltd, St Leonards, NSW, Australia) is effective against larvae and adults. Deltamethrin (Arrest Easy Dose Pour-on Cattle Lice and Fly Treatment ${ }^{\mathrm{TM}}$, $15 \mathrm{~g} / \mathrm{L}$ AC; Intervet Rural Co. Pty Ltd, East Bendigo, Vic, Australia) was applied to cattle during their induction from April to September.

\section{Identification of larvae and pupae}

The keys of Ferrar (1979) and Skidmore (1985) were used to identify larvae and pupae.

\section{Results}

Species composition and seasonality of fly larvae and pupae at selected developmental sites at the $S Q$ feedlot

The three main species of immature flies collected at the SQ feedlot were M. domestica, S. calcitrans and Physiphora clausa Macquart. On a single occasion, specimens of the bush fly Musca vetustissima Walker, a pest species which normally develops in the undisturbed manure pats of pastured cattle, were found under a fence line. Immatures of all other species combined accounted for $<1 \%$ of the total collection and are not reported herein. Larvae and pupae of $M$. domestica accounted for $82.9 \%(n=3589)$ and $83.9 \%(n=1878)$, respectively, of the immature stages collected, and were followed by collections of S. calcitrans and P. clausa (Table 3).

Both $M$. domestica and $S$. calcitrans larvae and pupae were found at all sites sampled (Table 3). Larvae of $M$. domestica were most abundant in the hospital and induction area and the cattle pens and least abundant in the horse stables and yards. The highest numbers of $M$. domestica pupae were found in the hospital and induction area and the drains and the lowest numbers in the horse stables and yards. Larvae of $S$. calcitrans were most abundant in the drains and least abundant in the horse stables and yards. The highest numbers of S. calcitrans pupae were found in the drains and the lowest numbers in the old cattle pens (Table 3). 
Table 2. Insecticide applications on the southern Queensland feedlot between October 2001 and October 2003.

\begin{tabular}{|c|c|c|c|}
\hline Active constituent & Application date & Type & Application sites \\
\hline Trichlorfon* & 23 January 2002 & Residual spray & $\begin{array}{l}\text { Feed bunks } \\
\text { Sedimentation pond } \\
\text { Loading ramp }\end{array}$ \\
\hline Betacyfluthrin $\dagger$ & 23 January 2002 & Residual spray & $\begin{array}{l}\text { Induction shed } \\
\text { Hospital } \\
\text { Horse stables } \\
\text { Feed mill } \\
\text { Lunch room }\end{array}$ \\
\hline & 11 February 2002 & Residual spray & $\begin{array}{l}\text { Feed bunks } \\
\text { Water troughs } \\
\text { Fence lines and tree lines } \\
\text { (new pens) } \\
\text { Loading ramp } \\
\text { Ends of cattle pens }\end{array}$ \\
\hline Methomyl\$ & As needed 2002 & Granular bait & $\begin{array}{l}\text { Induction shed } \\
\text { Hospital } \\
\text { Horse stables } \\
\text { Grain pad } \\
\text { Workshop } \\
\text { Dam } \\
\text { Sedimentation ponds } \\
\text { Water troughs } \\
\text { Tree lines }\end{array}$ \\
\hline & 11 February 2002 & Granular bait & $\begin{array}{l}\text { Feed bunks } \\
\text { Tree lines (new pens) } \\
\text { Hospital }\end{array}$ \\
\hline Trichlorfon§ & $\begin{array}{l}28 \text { January } 2003 \\
25 \text { April } 2003\end{array}$ & $\begin{array}{l}\text { Residual spray } \\
\text { Residual spray }\end{array}$ & $\begin{array}{l}\text { Feed bunks } \\
\text { Feed bunks }\end{array}$ \\
\hline Methomyl $\neq$ & As needed 2003 & Granular bait & $\begin{array}{l}\text { Induction area } \\
\text { Hospital } \\
\text { Feed mill }\end{array}$ \\
\hline
\end{tabular}

*Neguvon ${ }^{\circledR}$ SP (trichlorfon), $800 \mathrm{~g} / \mathrm{kg}$ AC; Bayer AG, Leverkusen, Germany.

$\dagger$ Solfac ${ }^{\circledR}$ Pro Residual Insecticide (betacyfluthrin), $25 \mathrm{~g} / \mathrm{L}$ AC; Bayer Environmental Science, East Hawthorn, Vic, Australia (formulation: $10 \mathrm{~mL}: \mathrm{L}$ $\mathrm{H}_{2} \mathrm{O}$ ).

$\ddagger$ Dy-Fly ${ }^{\circledR}$ Plus Fly Bait (methylomyl), 10 g/L AC; Bayer Environmental Science, East Hawthorn, Victoria, Australia.

§Dipterex ${ }^{\circledR} 500$ SL (trichlorfon), 500 g/L AC; United Phosphorus Ltd, St. Leonards, NSW, Australia (formulation: $180 \mathrm{~mL}: 10$ L).

Table 3. Mean numbers of fly larvae and pupae collected from selected sites at the southern Queensland feedlot from October 2001 to October 2003.

\begin{tabular}{|c|c|c|c|c|c|c|c|c|}
\hline \multirow[b]{2}{*}{ Feedlot site } & \multicolumn{4}{|c|}{ Larvae, $n$} & \multicolumn{4}{|c|}{ Pupae, $n$} \\
\hline & $M . d$ & S. c. & P.c. & Total & $M . d$. & S. c. & P.c. & Total \\
\hline Sedimentation ponds & 450 & 77 & 27 & 554 & 174 & 28 & 4 & 206 \\
\hline Horse stables and yards & 132 & 14 & 2 & 148 & 20 & 15 & 2 & 37 \\
\hline Manure stockpiles & 379 & 36 & 37 & 452 & 177 & 24 & 10 & 211 \\
\hline Old cattle pen & 621 & 26 & 2 & 649 & 178 & 6 & 0 & 184 \\
\hline New cattle pen & 595 & 49 & 2 & 646 & 226 & 17 & 1 & 244 \\
\hline Silage pits & 383 & 40 & 48 & 471 & 343 & 36 & 21 & 400 \\
\hline Drains & 341 & 216 & 6 & 563 & 377 & 102 & 18 & 497 \\
\hline Hospital and induction area & 688 & 152 & 4 & 844 & 383 & 76 & 1 & 460 \\
\hline
\end{tabular}

M.d., Musca domestica; P.c., Physiphora clausa; S.c., Stomoxys calcitrans.

As expected, larvae and pupae were not distributed uniformly across feedlot sites. At manure stockpiles, most larvae were found in the manure most recently added from the sedimentation pond (sample 5). In cattle pens, most larvae were collected from under fences (samples 3-5), with some near the feed bunk (sample 1), but few within the cattle pen (sample 2). In silage pits, most larvae were collected at the silage face (average of samples 4 and 5), and lower numbers were 
Table 4. Mean numbers of larvae extracted from different sites at the southern Queensland feedlot from October 2001 to October 2003.

\begin{tabular}{|c|c|c|c|c|c|c|}
\hline \multirow[b]{2}{*}{ Site } & \multicolumn{5}{|c|}{ Sample location number* } & \multirow{2}{*}{$\begin{array}{l}\text { Cumulative } \\
\text { mean }\end{array}$} \\
\hline & 1 & 2 & 3 & 4 & 5 & \\
\hline Sedimentation ponds & 169 & 97 & 89 & 110 & 99 & 112 \\
\hline $\begin{array}{l}\text { Horse stables and } \\
\text { yards } \dagger\end{array}$ & 36 & 36 & 6 & 42 & 75 & 43 \\
\hline Manure stockpiles & 59 & 65 & 100 & 74 & 166 & 91 \\
\hline Old cattle pen & 65 & 6 & 189 & 196 & 203 & 131 \\
\hline New cattle pen & 117 & 42 & 168 & 156 & 173 & 131 \\
\hline Silage pits & 37 & 43 & 143 & 109 & 209 & 100 \\
\hline Drains $\ddagger$ & 127 & 78 & 143 & 123 & 100 & 114 \\
\hline $\begin{array}{l}\text { Hospital and } \\
\text { induction area§ }\end{array}$ & 319 & 330 & 219 & - & - & 289 \\
\hline
\end{tabular}

*Indicates the five locations or general areas sampled within each site. $\dagger$ Sampled at five locations from 2001 to 2002 and two locations in 2003.

$\ddagger$ Sampled from January to October 2003.

$\S$ Sampled at three locations only from January to October 2003.

found at the pit entrance (sample 1) and in the middle of the pit (samples 2 and 3) (Table 4). Data for pupae are not shown, but followed a similar trend.

Larval abundance followed a seasonal trend, with few larvae detected during the cold winter months (July-September) (Fig. 1). Musca domestica larvae demonstrated broad peaks in population extending over 9-10 months each year. Stomoxys calcitrans larvae were most abundant in the autumn months of March-May 2003 and showed minor peaks in abundance during April-May and October-November 2002. Larval abundance ratings recorded in the feedlot and numbers of larvae extracted in the laboratory from corresponding samples followed similar trends (Fig. 1).

Species composition and relative abundances of larvae and pupae at feedlots in three different climatic regions

The same three fly species were observed at the feedlots in CNSW, SQ and CQ during summer and early autumn (Table 5). The CQ feedlot had the highest larval population ( $n=1899)$. Musca domestica was the most numerous species at all three feedlots and constituted $>90 \%$ of larvae collected at the SQ (total $=1121$ ) and CQ (total =1727) feedlots. Stomoxys calcitrans comprised $13 \%$ (total $=97), 6 \%($ total $=$ 72 ) and $1 \%$ (total $=11$ ) of the larvae extracted in the CNSW, SQ and CQ feedlots, respectively. Other fly larvae at all feedlots were primarily $P$. clausa.

Pupal and larval ratings were similar at the CNSW feedlot, but pupal ratings were lower than larval ratings at the other two feedlots (Table 5). Musca domestica was again the dominant species, with mean sample numbers of 307, 683 and 315 at the CNSW, SQ and CQ feedlots, respectively. Stomoxys calcitrans comprised just $4 \%($ mean $=29)$ and $1 \%($ mean $=4)$ of pupae collected at the SQ and CQ feedlots, respectively. However in the CNSW feedlot, $S$. calcitrans comprised 39\% (mean $=220)$ of the pupae and the S. calcitrans : M. domestica ratio was higher for pupae than for larvae. Other fly pupae at all feedlots were primarily $P$. clausa.

\section{Weather data}

Temperature profiles were similar for both study years (Fig. 1), with minimum and maximum temperatures of $-6{ }^{\circ} \mathrm{C}$ [1 August 2003 (winter)] and $40{ }^{\circ} \mathrm{C}$ [12 January 2002 (summer)], respectively. Compared with 46-year averages, night temperatures in July 2002 were lower than average, and summer 2002 and spring and early summer 2003 were warmer than average.

Rainfall occurred on 180 (24\%) of the 750 study days, with a maximum of $50 \mathrm{~mm}$ recorded on 23 February 2003. Rainfall totals for the first and second study years were $558 \mathrm{~mm}$ and $577 \mathrm{~mm}$, respectively $(50$-year mean $=611 \mathrm{~mm})$. Most rain (75\%) fell from October to March, but rainfall in January in 2002 and 2003 was well below the 50-year average.

\section{Effects of feedlot design and management practices at the $S Q$ feedlot}

Larval population levels in new cattle pens with a $3 \%$ slope and old cattle pens with a minimal slope were similar (Table 4). After some, but not all, pen-cleaning events, a reduction in numbers of larvae was observed (Fig. 2). However, the reduction generally lasted only $1-2$ weeks.

The four major insecticide treatments (various combinations of trichlorfon, cyfluthrin and fly baits) applied over the 2-year period had little impact on larval abundance in either the old or new pens (Fig. 3). Major changes in larval abundance coincided with seasonal climatic conditions. Insecticide treatments may have caused minor, short-term reductions in larval populations (e.g. February 2002 treatment) or accelerated seasonal reductions in larval populations caused by cooler temperatures (e.g. April 2003 treatment) (Fig. 3). Similar observations were made for the sedimentation pond, which was sprayed with insecticides in early 2002.

\section{Discussion}

This project is the first of its kind in Australia and only one similar project conducted in the U.S.A. has been reported in the literature (Campbell \& McNeal, 1979). Feedlot fly management has been investigated previously (Petersen et al., 1983; Skoda et al., 1991, 1993; Thomas et al., 1996; Weinzierl \& Jones, 1998), but the study sites in these earlier investigations were located in temperate areas with 3-month summer fly seasons. Comparisons with our study in Australia, where flies are active throughout the year, are difficult. Although our project was designed to enable statistical analysis, this was precluded by sample variance. Inferences are based on numerical trends in the data.

The dominance of $M$. domestica and $S$. calcitrans in eastern Australia resembles that observed in similar environments on 


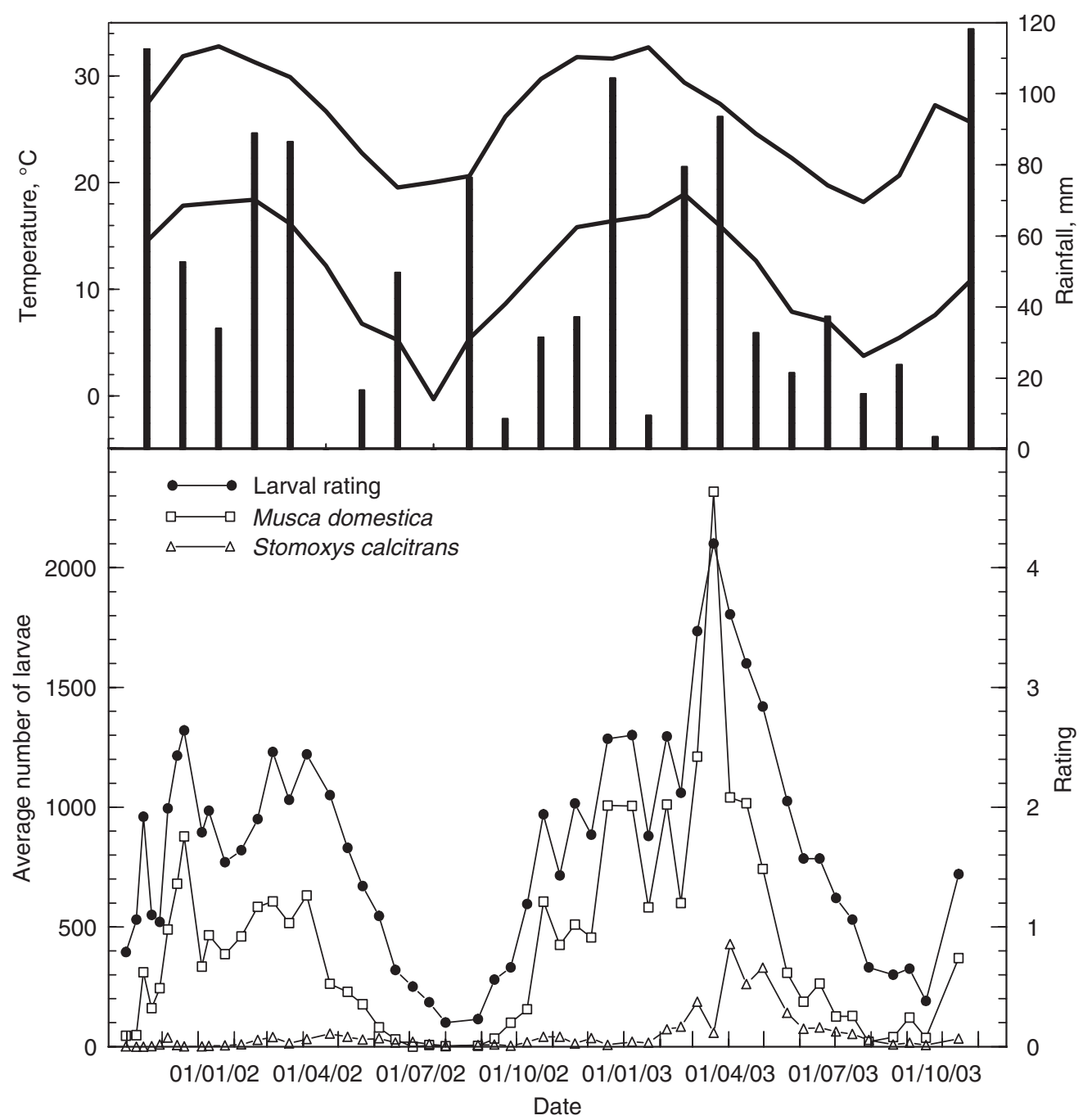

Fig. 1. Average larval abundance ratings and numbers of Musca domestica and Stomoxys calcitrans larvae recovered from southern Queensland feedlot samples (across all sites) and monthly averages of daily minimum and maximum temperatures (lines) and monthly rainfall (bars) for the period from October 2001 to October 2003.

Table 5. Mean larval and pupal ratings and mean numbers and percentage composition of extracted larvae and pupae of Musca domestica, Stomoxys calcitrans and other flies at three feedlots.

\begin{tabular}{|c|c|c|c|c|}
\hline \multirow[b]{2}{*}{ Indicator } & \multirow[b]{2}{*}{ Flies } & \multicolumn{3}{|l|}{ Feedlot } \\
\hline & & $\mathrm{CNSW}^{*}$ & $\mathrm{SQ} \dagger$ & $\mathrm{CQ} F$ \\
\hline Larval rating & - & 2.7 & 2.8 & 4.3 \\
\hline \multirow[t]{4}{*}{ Larvae extracted, mean $(\%)$} & M. domestica & $562(77 \%)$ & $1121(92 \%)$ & $1727(91 \%)$ \\
\hline & S. calcitrans & $97(13 \%)$ & $72(6 \%)$ & $11(1 \%)$ \\
\hline & Other flies & $72(10 \%)$ & $30(2 \%)$ & $161(8 \%)$ \\
\hline & Total & 731 & 1223 & 1899 \\
\hline Pupal rating & - & 2.4 & 1.9 & 2.2 \\
\hline \multirow[t]{4}{*}{ Pupae extracted, mean (\%) } & M. domestica & $307(54 \%)$ & $683(94 \%)$ & $315(60 \%)$ \\
\hline & S. calcitrans & $220(39 \%)$ & $29(4 \%)$ & $4(1 \%)$ \\
\hline & Other flies & $41(7 \%)$ & $9(2 \%)$ & $204(39 \%)$ \\
\hline & Total & 568 & 721 & 523 \\
\hline
\end{tabular}

*Central New South Wales: 15 January 2003.

$\dagger$ Southern Queensland: average for January-March 2003.

†Central Queensland: 26 March 2003.

Published 2011. This article is a U.S. Government work and is in the public domain in the USA. Medical and Veterinary Entomology, 26, 46-55 


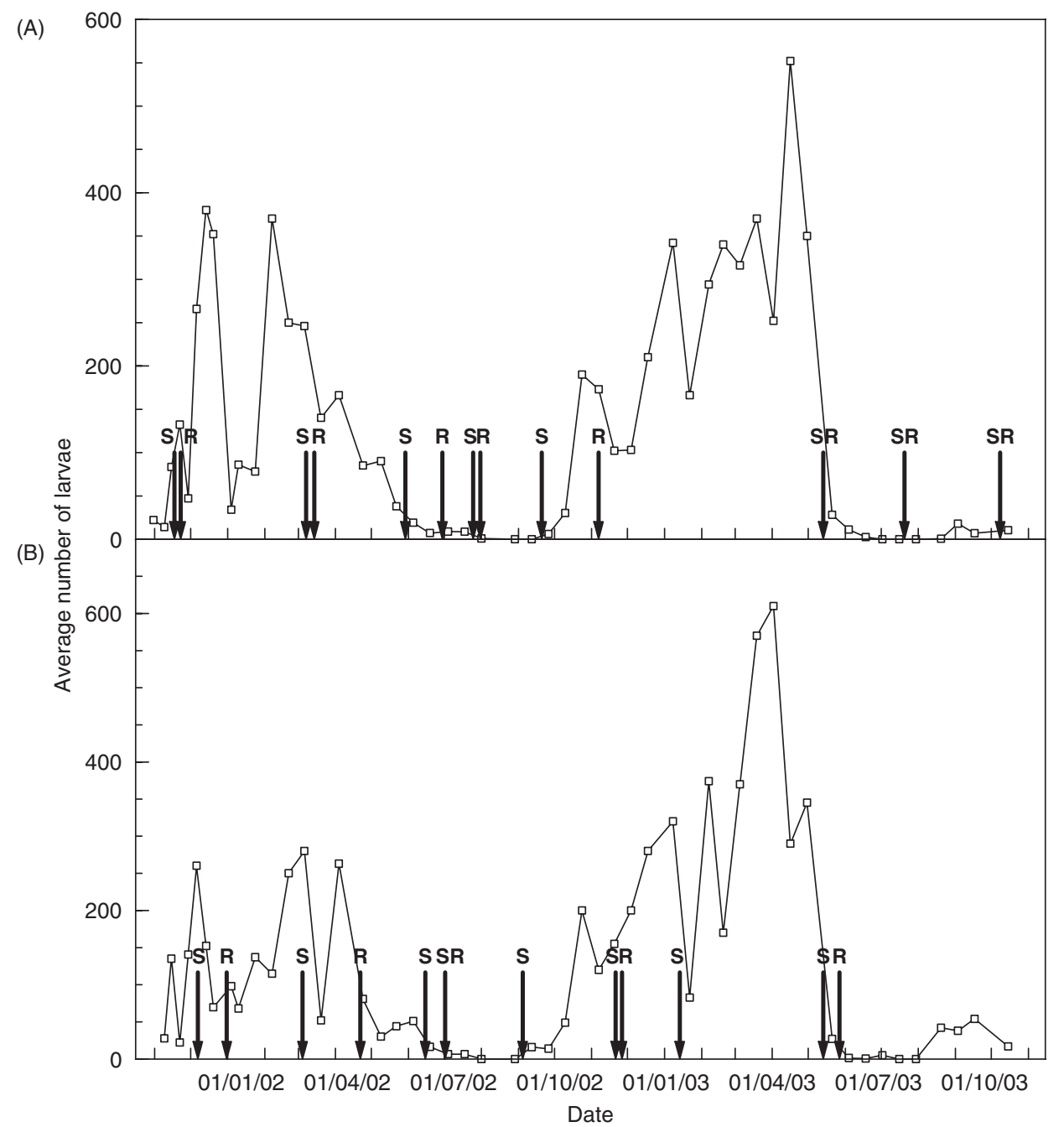

Fig. 2. Average numbers of larvae and timing of cleaning in the (A) new and (B) old cattle pens at the southern Queensland feedlot. R, manure removed; $\mathrm{S}$, manure scraped.

other continents (Raspi \& Belcari, 1989; Skoda et al., 1991, 1993; Petersen \& Cawthra, 1995; Marchiori et al., 2000) and was therefore not unexpected. Physiphora clausa, a common manure-breeding fly (Raspi \& Belcari, 1989), is not known to be a nuisance to cattle or humans and its presence in collections is often not reported (J. A. Hogsette, unpublished data, 2003). At the SQ feedlot, 25 species of adult flies were trapped during our larval and pupal surveys (R. Urech, unpublished data, 2003). This demonstrates that many of the adult fly species found on the feedlot were not bred on site.

Climate had a strong impact on immature fly populations. Numbers were low during winter months (June-August), but a few larvae and pupae were found in every collection. Musca domestica larvae were found in moderate to high numbers during most of the year on the SQ feedlot. This is similar to larval seasonality in North Florida (Romero et al., 2010), but contrasts sharply with data from Nebraska, where optimal summer conditions are brief and winters are harsh (Meyer \& Petersen, 1983; Skoda et al., 1993). We observed peak larval numbers after rainfall in spring, summer and autumn. Larval populations of S. calcitrans were low during the coldest and warmest seasons and most abundant during autumn and spring. In Florida, this species peaks during the mild winters and populations are low during the hot, dry summers (Romero et al., 2010). The optimal developmental temperature for S. calcitrans is lower than for $M$. domestica (Larsen \& Thomsen, 1940).

Trends among visually assigned larval abundance ratings and the number of larvae extracted from the same samples in the laboratory were similar enough to validate the small trowel method of obtaining field estimates of immature fly populations. The equipment was portable and the method allowed trained personnel to process large numbers of samples in a relatively short period.

The largest numbers of fly larvae were found in feedlot sites with high proportions of uncompacted, moist manure, feed or vegetation, as reported by Meyer \& Petersen (1983) and Hogsette et al. (1987). The hospital and induction area had 


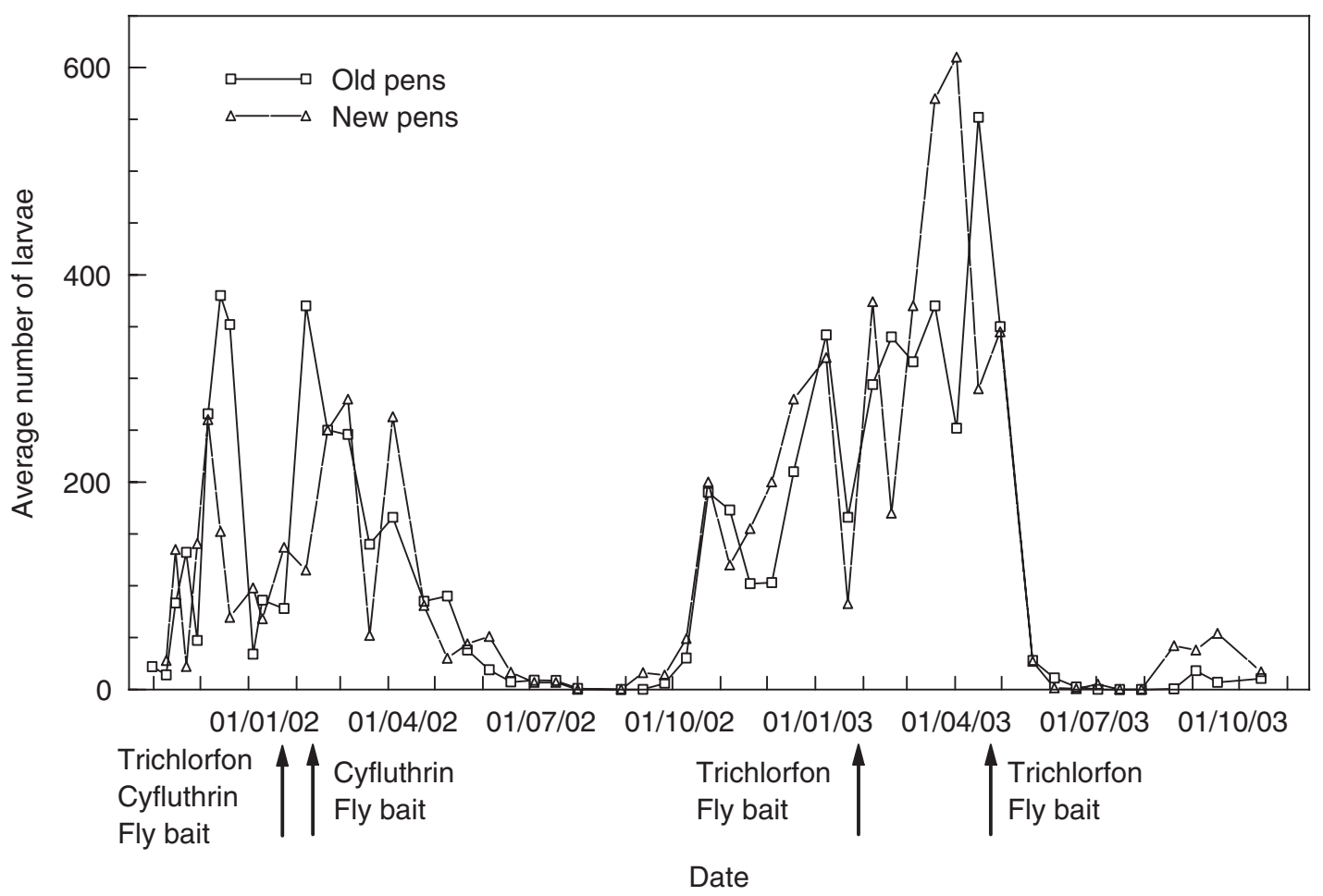

Fig. 3. Average numbers of larvae and timing of insecticidal treatments in the old and new cattle pens at the southern Queensland feedlot.

a high proportion of fence lines and uncompacted manure, and the highest populations of housefly larvae. Hay used as a supplemental feed in the hospital area became an excellent substrate for the development of flies, particularly of S. calcitrans (Hogsette et al., 1987; Broce et al., 2005). The cattle pens supported large larval populations, mainly under fence lines, and particularly near the water troughs centred along side fences. Campbell \& McNeal (1979) first noted the use of manure accumulations under fences for larval development. Larval density was lowest inside the pens, higher near feed bunks, but much higher under fences, as reported by Skoda et al. (1991, 1993) in Nebraska. Larval density extremes in and around cattle pens showed a 30-fold difference.

Similar numbers of fly larvae in old and new pens indicated that no apparent benefit derived from the increased slope and improved drainage. However, design differences in new pens may have been negated by other factors, such as the shade cloth under which cattle tended to congregate.

Liquid and solid silage constituents provided an excellent medium for stable fly and housefly development. Silage in pit and bunker silos is one of the most important semipermanent habitats for fly development on livestock facilities (Hogsette et al., 1987). The best developmental sites were at the silage face, but the pock-marked base of the pits allowed fly development to occur in spilt silage along the length of the pits. Silage pits were used intermittently after November 2002, but remained empty from June 2003 because of prolonged drought and high silage prices.

The scraping of pens and removal of manure every 2-4 months produced a short-term reduction in fly larvae at best. One strategy to reduce fly breeding in pens involves the more frequent removal of manure from under fences and less frequent cleaning out of complete pens. Thomas et al. (1996) demonstrated that stable fly populations can be reduced by the frequent removal of manure from pens, but this may not be practical or economically feasible in large facilities such as the SQ feedlot.

Insecticides were applied to feedlot areas in which populations of immature flies were perceived to be high. Our data indicate that larval abundance was not substantially reduced by any such treatment. The failure of insecticides to control immature stages largely reflects the lack of contact between the treatment and the target insects (Farkas \& Hogsette, 2000). Breeding substrates usually protect larvae from spray treatments and pupae are impervious to pesticides. In addition, weekly (October-December 2001) and fortnightly (January 2002 to October 2003) population monitoring may not have been sensitive enough to detect population reductions that persisted for less than one monitoring interval.

In summary, this is the first large-scale survey of immature fly populations to be conducted on Australian feedlots. Houseflies and stable flies were the two main pest species produced on the feedlots. The small trowel sampling method was reliable enough to provide field estimates of larval populations similar to those produced in the laboratory by separating larvae from field-collected substrates using labour-extensive techniques. Mechanical and chemical fly management techniques did not produce measurable reductions in fly populations and further research is needed to establish strategies for successfully accomplishing this task. 


\section{Acknowledgements}

Funding for this study was provided by Meat \& Livestock Australia (MLA). We thank Des Rinehart (MLA) for technical advice and the feedlot owners for the use of their facilities.

\section{References}

Australian Lot Feeders' Association (2009) Australian Lot Feeders' Association/Meat \& Livestock Australia National Accredited Feedlot Survey July-September 2009. www.feedlots.com.au/images/ stories/SURVEY/mrsep09.pdf [Accessed October 2011].

Broce, A.B., Hogsette, J.A. \& Paisley, S. (2005) Winter feeding sites of hay in round bales as major developmental sites of Stomoxys calcitrans (Diptera: Muscidae) in pastures in spring and summer. Journal of Economic Entomology, 98, 2307-2312.

Campbell, J.B. \& Berry, I.L. (1989) Economic threshold for stable flies on confined livestock. Current Status of Stable Fly (Diptera: Muscidae) Research, Vol. 74 (ed. by J. J. Petersen \& G. L. Greene), pp. 18-22. Entomological Society of America, Lanham, MD.

Campbell, J.B. \& McNeal, C.D. Jr (1979) A Guide to Integrated Pest Management at Feedlots and Dairies. University of Nebraska Cooperative Extension Service, Lincoln, NE.

Campbell, J.B., Skoda, S.R., Berkebile, D.R., Boxler, D.J., Thomas, G.D., Adams, D.C. \& Davis, R. (2001) Effects of stable flies (Diptera: Muscidae) on weight gains of grazing yearling cattle. Journal of Economic Entomology, 94, 780-783.

Catangui, M.A., Campbell, J.B., Thomas, G.D. \& Boxler, D.J. (1997) Calculating economic injury levels for stable flies (Diptera: Muscidae) on feeder heifers. Journal of Economic Entomology, 90, 6-10.

Cilek, J.E. \& Greene, G.L. (1994) Stable fly (Diptera: Muscidae) insecticide resistance in Kansas cattle feedlots. Journal of Economic Entomology, 87, 275-279.

CLIMARC (2006) Climate averages (by state). www.bom.gov.au/ climate/how/climarc.shtml [Accessed 6 October 2011].

Cook, D.F., Dadour, I.R. \& Keals, N.J. (1999) Stable fly, house fly (Diptera: Muscidae), and other nuisance fly development in poultry litter associated with horticultural crop production. Journal of Economic Entomology, 92, 1352-1357.

De Jesus, A.J., Olsen, A.R., Bryce, J.R. \& Whiting, R.C. (2004) Quantitative contamination and transfer of Escherichia coli from foods by houseflies, Musca domestica L. (Diptera: Muscidae). International Journal of Food Microbiology, 93, 259-262.

Eghball, B. \& Power, J.F. (1994) Beef cattle feedlot manure management. Journal of Soil and Water Conservation, 49, 113-122.

Farkas, R. \& Hogsette, J.A. (2000) Control possibilities of filthbreeding flies in livestock and poultry production. Contributions to a Manual of Palearctic Diptera, Vol. 1. General and Applied Dipterology (ed. by L. Papp \& B. Darvas), pp. 889-904. Science Herald, Budapest.

Ferrar, P. (1979) The immature stages of dung-breeding Muscoid flies in Australia, with notes on the species, and keys to larvae and puparia. Australian Journal of Zoology, Supplementary Series, 73, $1-106$.

Floate, K.D. (2003) Field trials of Trichomalopsis sarcophagae (Hymenoptera: Pteromalidae) in cattle feedlots: a potential biocontrol agent of filth flies (Diptera: Muscidae). Canadian Entomologist, 135, 599-608.
Graczyk, T.K., Knight, R. \& Tamang, L. (2005) Mechanical transmission of human protozoan parasites by insects. Clinical Microbiology Reviews, 18, 128-132.

Greenberg, B. (1971) Flies and Disease, Ecology, Classification, and Biotic Association, Vol. 2. Princeton University Press, Princeton, NJ.

Hogsette, J.A. (1996) Development of house flies (Diptera: Muscidae) in sand containing varying amounts of manure solids and moisture. Journal of Economic Entomology, 89, 940-945.

Hogsette, J.A. (1999) Management of ectoparasites with biological control organisms. International Journal for Parasitology, 29, $147-151$.

Hogsette, J.A. \& Farkas, R. (2000) Secretophagous and haematophagous higher Diptera. Contributions to a Manual of Palearctic Diptera, Vol. 1. General and Applied Dipterology (ed. by L. Papp \& B. Darvas), pp. 769-792. Science Herald, Budapest.

Hogsette, J.A., Ruff, J.P. \& Jones, C.J. (1987) Stable fly biology and control in northwest Florida. Journal of Agricultural Entomology, 4, $1-11$.

Kaufman, P.E., Rutz, D.A. \& Frisch, S. (2001) Sticky traps for large scale house fly (Diptera: Muscidae) trapping in New York poultry facilities. Journal of Agricultural and Urban Entomology, 18, 43-49.

Kocisova, A., Novak, P., Toporcak, J. \& Petrovsky, M. (2002) Development of resistance in field housefly (Musca domestica): comparison of effects of classic spray regimes versus integrated control methods. Acta Veterinaria Brno, 71, 401-405.

Larsen, E.B. \& Thomsen, M. (1940) The influence of temperature on the development of some species of diptera. Videnskabelige Meddelelser Dansk Naturhistorisk Forening, 104, 1-75.

Levot, G.W. \& Hughes, P.B. (1989) Insecticide resistance in flies (Diptera: Muscidae) from poultry farms. Journal of the Australian Entomological Society, 28, 87-91.

Levot, G.W. \& Hughes, P.B. (1995) Seasonal abundance of nuisance flies on commercial egg farms. General and Applied Entomology, 26, 25-30.

Marchiori, C.H., Vieira, C.I.S., Caldas, E.R., Teixeira, F.F., Silva, C.G. \& Linhares, A.X. (2000) Muscoid dipterous insects associated with cattle feces and their parasitoids in Goias State, Brazil. Arquivo Brasileiro de Medicina Veterinaria e Zootecnia, 52, 354-356.

Marçon, P., Thomas, G.D., Siegfried, B.D., Campbell, J.B. \& Skoda, S.R. (2003) Resistance status of house flies (Diptera: Muscidae) from southeastern Nebraska beef cattle feedlots to selected insecticides. Journal of Economic Entomology, 96, 1016-1020.

Meyer, J.A. \& Petersen, J.J. (1983) Characterization and seasonal distribution of breeding sites of stable flies and house flies (Diptera: Muscidae) on Eastern Nebraska feedlots and dairies. Journal of Economic Entomology, 76, 103-108.

Mullens, B.A., Gerry, A.C. \& Diniz, A.N. (2010) Field and laboratory trials of a novel Metaflumizone house fly (Diptera: Muscidae) bait in California. Journal of Economic Entomology, 103, $550-556$.

Petersen, J.J. \& Cawthra, J.K. (1995) Release of a gregarious Muscidifurax species (Hymenoptera: Pteromalidae) for the control of filth flies associated with confined beef cattle. Biological Control, $\mathbf{5}$, 279-284.

Petersen, J.J., Meyer, J.A., Stage, D.A. \& Morgan, P.B. (1983) Evaluation of sequential releases of Spalangia endius (Hymenoptera: Pteromalidae) for control of house flies and stable flies (Diptera: Muscidae) associated with confined livestock in eastern Nebraska. Journal of Economic Entomology, 76, 283-286. 
Pitzer, J.B., Kaufman, P.E. \& TenBroeck, S.H. (2010) Assessing permethrin resistance in the stable fly (Diptera: Muscidae) in Florida by using laboratory selections and field evaluations. Journal of Economic Entomology, 103, 2258-2263.

Raspi, A. \& Belcari, A. (1989) Some qualitative and quantitative observations on the dipteran fauna present in dairy cattle housing. Frustula Entomologica, 12, 1-13.

Romero, A., Hogsette, J.A. \& Coronado, A. (2010) Distribution and abundance of natural parasitoid (Hymenoptera: Pteromalidae) populations of house flies and stable flies (Diptera: Muscidae) at the University of Florida Dairy Research Unit. Neotropical Entomology, 39, 424-429.

Skidmore, P. (1985) The Biology of the Muscidae of the World, Series Entomologica, Vol. 29. Junk, Dordrecht.

Skoda, S.R., Thomas, G.D. \& Campbell, J.B. (1991) Developmental sites and relative abundance of immature stages of the stable fly (Diptera: Muscidae) in beef cattle feedlot pens in eastern Nebraska. Journal of Economic Entomology, 84, 191-197.

Skoda, S.R., Thomas, G.D. \& Campbell, J.B. (1993) Abundance of immature stages of the house fly (Diptera: Muscidae) from five areas in beef cattle feedlot pens. Journal of Economic Entomology, 86, 455-461.

Skovgard, H. \& Nachman, G. (2004) Biological control of house flies Musca domestica and stable flies Stomoxys calcitrans (Diptera: Muscidae) by means of inundative releases of Spalangia cameroni (Hymenoptera: Pteromalidae). Bulletin of Entomological Research, 94, 555-567.

Thomas, G.D., Skoda, S.R., Berkebile, D.R. \& Campbell, J.B. (1996) Scheduled sanitation to reduce stable fly (Diptera: Muscidae) populations in beef cattle feedlots. Journal of Economic Entomology, 89, 411-414.

Weinzierl, R.A. \& Jones, C.J. (1998) Releases of Spalangia nigroaenea and Muscidifurax raptor (Hymenoptera: Pteromalidae) increase rates of parasitism and total mortality of stable fly and house fly (Diptera: Muscidae) pupae in Illinois cattle feedlots. Journal of Economic Entomology, 91, 1114-1121.

Accepted 17 May 2011

First published online 31 October 2011 